\title{
Intake of ashe juniper and live oak by angora goats
}

\author{
R.R. RIDDLE, C.A. TAYLOR, JR., J.E. HUSTON, AND M.M. KOTHMANN
}

Authors are former graduate student, Department of Rangeland Ecology and Management; professor, Texas Agricultural Experiment Station, Sonora, Tex. 76950; professor, Texas Agricultural Experiment Station, San Angelo, Tex. 76901; professor, Department of Rangeland Ecology and Management, Texas A\&M University, College Station, Tex. 77843; current address for Riddle; USDA-Natural Resources Conservation Service, Federal Building 39N. Washington, RM 109. Ardmore, Okla 73401-7012.

\section{Abstract}

Angora mutton goats (Capra hircus) were fed diets of either live oak [Quercus virginiana (Small) Sarg. var. fusiformis], alfalfa hay (Medicago sativa L.), Coastal bermudagrass hay (Cynodon dactylon (L.)Pers.) or female ashe juniper (Juniperus ashei Buchholz) plus Coastal bermudagrass hay during the spring and fall of 1991 in a digestion/metabolism study. Nitrogen concentration of Coastal bermudagrass hay was nearly equal to that of alfalfa hay; nitrogen concentration of ashe juniper and live oak were much lower than those of the hays, and were higher in fall than spring. Dry matter intake and dietary nitrogen were highest for alfalfa hay, intermediate for Coastal bermudagrass hay, and lower for ashe juniper and live oak. Goats retained more nitrogen when consuming alfalfa and Coastal bermudagrass hays than juniper or live oak during fall, but differences were smaller $(P>0.10)$ during spring. Nitrogen balance was negative for goats consuming live oak in the spring. Nitrogen balance was positive for live oak in the fall and positive for ashe juniper for the spring and fall. Animals fed hay diets had higher levels of urine output than those fed juniper or live oak. Dry matter digestibility of juniper and live oak diets was less in fall than in spring. During fall, dry matter intakes of juniper and live oak were significantly lower than those of alfalfa and Coastal bermudagrass hays. We conclude that both ashe juniper and live oak foliage can provide nutrients for goats but only as portions of diets.

Key Words: Capra, digestibility, Quereus virginiana, Juniperus ashei, Edwards Plateau, nitrogen

The increase of juniper (Juniperus spp. L) in the Edwards Plateau region of south-central Texas over the past hundred years has decreased forage production for grazing animals. The forage value of juniper is considered relatively low (Pritz et al. 1997), and vegetation growth beneath its canopy is reduced (Fuhlendorf et al. 1996). Juniper growth in the presence of desirable rangeland flora may cause disappearance of the more desired forage species with time (Rykiel and Cook 1986; Fuhlendorf and Smeins 1997).

Authors wish to thank Ray Hinnant for his assistance with statistical analyses. Manuscript accepted 3 Jul. 1998.

\section{Resumen}

Durante la primavera y otoño de 1991 se realizó un estudio de digestión/metabolismo en el que machos caprinos de angora (Capra hircus) fueron alimentados con "Live oak" [Quercus virginiana (Small) Sarg. Var fusiformis], heno de Alfalfa (Medicago sativa L.) y heno de Bermuda de la costa (Cynodon dactylon (L.) Pers.) o con "Female ashe juniper" (Juniperus ashei Buchholz) mas heno de Bermuda de la costa. La concentración de nitrógeno del heno de Bermuda de la costa fue casi igual a la del heno de Alfalfa. Las concentraciones de nitrógeno de “Ashe juniper' y "Live oak" fueron mucho más bajas que la de los henos de Alfalfa y Bermuda de la costa y fueron mayores en otoño que en primavera. El consumo de materia seca y el nitrógeno dietario fueron mayores para heno de Alfalfa, intermedio para el heno de Bermuda de la costa y bajo para "Ashe juniper" y "Live oak" En otoño, las cabra retuvieron más nitrógeno cuando consumieron heno de Alfalfa o Bermuda de la costa que cuando consumieron "Ashe juniper" o "live oak"; sin embargo, las diferencias en primavera fueron pequeñas $(P>0.10)$. En primavera, el balance de nitrógeno de cabras consumiendo "Live oak" fue negativo. En otoño, el balance de nitrógeno fue positivo para "Live oak", para "Ashe juniper" fue positivo en primavera y otoño. Los animales alimentados con dietas de heno tuvieron mayores niveles de rendimientos de orina que los alimentados con "Ashe juniper "o "Live oak". La digestibilidad de la materia seca de las dietas de "Ashe juniper" y 'Live oak' fue menor en otoño que en primavera. Durante el otoño los consumos de materia seca de "Ashe juniper" y "Live oak" fueron significativamente menores que los de heno de Alfalfa y Bermuda de la costa. Concluimos que tanto el follaje de "Ashe juniper" como "Live oak" pueden proveer nutrientes a las cabras, pero solo como parte de la dieta.

As the region was settled, severe overgrazing reduced grass cover (Youngblood and Cox 1922), exposed soil and accelerated erosion. Recurrent droughts and control of naturally occurring fires, combined with the loss of grass cover, encouraged the growth of ashe juniper (Smeins 1990). Juniper encroachment continues to plague the area (Smeins and Merrill 1988) to the point where it has become the most crucial ecological and economical rangeland management issue on the Edwards Plateau (Smeins 1990).

Goat browsing can aid in the control of juniper (Taylor et 
al. 1997). In 1949, most of the junipers were removed from the Texas Agricultural Experiment Station (TAES) at Sonora, and the pastures were stocked with different combinations of sheep, cattle, and goats. Cattle and sheep primarily graze grasses. Goats, however, utilize both grasses and woody browse (Taylor 1992). At the TAES research station, long-term goat browsing dramatically suppressed juniper populations (Fuhlendorf et al. 1996). In pastures heavily used by goats, the number of juniper plants/ha was reduced by approximately $62 \%$. Also, the pastures browsed by goats had very few large seed producing trees. Although juniper is readily consumed by goats, its value as a source of nutrients is not known.

The objective of this study was to determine the forage value of ashe juniper for goats. Measurements include digestibility, metabolizability, and intake of ashe juniper relative to those of live oak, alfalfa hay, and Coastal bermudagrass hay.

\section{Materials and Methods}

\section{Experimental Area}

The study was conducted at the Texas A\&M Agricultural Experiment Station (TAES) located $45 \mathrm{~km}$ southeast of Sonora, Tex. $\left(31^{\circ} \mathrm{N} ; 100^{\circ} \mathrm{W}\right)$. The 1,377 ha research station was established in 1916 in Sutton and Edwards counties within the Edwards Plateau (Hatch et al. 1990) as a setting for sheep and goat research. The elevation of the research station is about 632 meters. The region is dominated by rangelands composed of mixtures of grasses, forbs, and woody species. The vegetation is a mosaic of juniper and oak mottes interspaced with midand shortgrasses. For a complete description of the climate, soils, and vegetation at the research station see Smeins et al. (1976).

Warm summers and mild winters allow for an average growing season (March through October) of 240 days. Average long-term precipitation of 609 $\mathrm{mm}$ is highly variable and skewed with more years of below average rainfall than above. Peak precipiation months are May, June, and September. Growing season precipiation averaged $409 \mathrm{~mm}$ over 70 years (Taylor et al. 1993).

The most common soils on the station are Tarrant silty clay and Tarrant stony clay (Clayey-skeletal, montmorillonitic, Lithic Calciustolls) with some Kavett silty clay soils (Clayey, montmorillonitic, thermic, lithic, Petrocalcic Calciustolls) in low-lying areas (Taylor et al. 1993). The Tarrant stony clays are the dominant soils which overlay a fractured limestone substrate and are generally 15 to 30 $\mathrm{cm}$ deep. These soils contain 5 to $70 \%$ limestone fragments or slabs of limestone outcrops. The topography is typified by rolling, stony hills with slopes of 3 to $4 \%$, which produce patterns of shallow divides, limestone outcrops, and low lying areas of deeper soils (USDA-SCS 1972).

\section{Experimental Design}

Metabolic trials were conducted to determine the intake, digestibility, and nitrogen balance of 4 diets by goats. Two goats were assigned randomly to each of the 4 diets in 5 trials of 15 days each (1 animal per stall). Each trial consisted of a 10-day adjustment period followed by a 5-day collection period for feces and urine. Data were averaged across days for each animal before analysis. Independent variables were diet (fixed), season (fixed), diet by season (fixed), trial within season (random), and diet and trial within season (random). Individual animals and trials were considered replicates. Standard errors (SE) and probabilities of differences (P) were used to make statistical inferences.

\section{Animals}

Thirteen mature Angora mutton goats ( 2 to 5 years old, $40 \pm 5 \mathrm{~kg}$ ) were used for the metabolic trials. Eight of the 13 goats ( 2 per diet) were used for each trial. Goats that were not being used in a trial were maintained on alfalfa hay ad libitum and a pelleted ration $(12 \% \mathrm{CP})$ consisting of $30 \%$ cottonseed hulls and 70\% concentrates. During the feeding trials, forages were presented ad libitum, and animals always had unlimited access to water and mineral blocks (contained salt and trace elements).

\section{Diets}

Experimental diets used in this study were alfalfa (AH) and Coastal bermudagrass $(\mathrm{CBH})$ hays, live oak foliage (LO), and ashe juniper foliage plus Coastal bermudagrass hay (Jun/CBH). Female ashe juniper was used in these trials because it was determined in preference trials (Riddle et al. 1996) to be the most preferred species and sex of juniper. Preliminary trials indicated that the animals could not be maintained on diets of only juniper for the 15-day test period. Therefore, animals assigned to the juniper diet were fed, in addition, Coastal bermudagrass hay. A Coastal bermudagrass treatment was added to assess the nutritive value of the grass hay and allow calculations by difference of the values for juniper. Alfalfa served as the control diet for these trials.

\section{Metabolic Trials}

The trials were conducted during spring ( 2 trials) and fall (3 trials) using metabolism stalls located in an open air building. Spring trials were conducted from 31 May-18 June. Fall trials were conducted from 24 October-26 November. Each stall measured $2.35 \times 1.14 \times 1.70 \mathrm{~m}$ and had an expanded steel floor to allow feces to drop through to collection pans which were covered with 0.03 $\mathrm{cm}$ mesh wire screen. Urine ran through the screen to a sloping pan surface which drained into collection vessels.

Juniper and live oak foliages were harvested daily and presented to the animals at approximately 1000 hours in a specially designed feeder, which could hold 6 branches at a time. The advantages of this type of feeder included easy removal and replacement of branches as well as the manner of presentation being similar to that of a real tree.

One unbrowsed portion of each forage was placed outside of the metabolism stalls to determine moisture loss and chemical content of the foliage. Moisture loss was calculated by the same method used for the preference trials (Riddle et al. 1996). After moisture loss had been determined, foliage samples were removed from the 
unbrowsed juniper and live oak branches to resemble the removal by goats from the browsed branches. Samples of the alfalfa and Coastal bermudagrass hays were also collected at this time, and the process was repeated at every feeding. Weights of diet, refusals, and feces were recorded. Subsamples of each were composited and stored at $-15^{\circ} \mathrm{C}$. Frozen samples were freeze-dried for subsequent laboratory analyses. Volatilization of ammonia from urine was prevented by the addition of $10 \mathrm{ml}$ of $25 \% \mathrm{H}_{2} \mathrm{SO}_{4}$ to the polypropylene urine containers. Dry matter (DM) and nitrogen were determined using standard procedures (AOAC 1965).

Contributions of juniper to the Jun/CBH diet were determined by difference. Intake and digestibility of the combined diet and dry matter proportions that each contributed to the diet were determined. Dry matter intake and fecal dry matter (FDM) contributed by the Coastal bermudagrass hay based on the digestibility estimate obtained for the Coastal bermudagrass hay diet were subtracted.

Calculations were made according to the following formulae;

$$
\begin{aligned}
& \operatorname{DMD}(\text { Jun })=\frac{\mathrm{DMI}(\mathrm{Jun})-\mathrm{FDM}(\mathrm{Jun})}{\mathrm{DMI}(\mathrm{Jun})} \\
& \begin{aligned}
& \text { where } \text { (1) } \\
& \operatorname{DMD}(\text { Jun })= \text { dry matter digestibility } \\
& \text { of juniper }
\end{aligned} \\
& \operatorname{DMI}(\text { Jun })=\begin{array}{l}
\text { dry matter intake of } \\
\text { juniper }
\end{array} \\
& \operatorname{FDM}(\text { Jun })=\begin{array}{l}
\text { fecal dry matter from } \\
\text { juniper }
\end{array}
\end{aligned}
$$
and

$$
\begin{aligned}
\operatorname{FDM}(\mathrm{Jun})= & \text { total feces }(\mathrm{Jun} / \mathrm{CB})- \\
& \operatorname{FDB}(\mathrm{CB})
\end{aligned}
$$

and

$$
\mathrm{FDM}(\mathrm{CB})=\underset{(\mathrm{CB}))}{\mathrm{DMI}(\mathrm{CB}) \times(1-\mathrm{DMD}}
$$

and

$$
\begin{aligned}
\mathrm{DMD}(\mathrm{CB})= & \text { dry matter digestibility } \\
& \text { of CB fed alone }
\end{aligned}
$$

\section{Statistical Analysis}

The data were analyzed by the General Linear Model (GLM) procedure (SAS 1988). The dependent variables were daily intake of dry matter $\left(\mathrm{g} \mathrm{day}^{-1}\right)$, fecal output $\left(\mathrm{g} \mathrm{day}^{-1}\right)$, water intake (liters day $^{-1}$ ), urine excretation (liters day $^{-1}$ ), dry matter digestibility $(\%)$, nitrogen intake $\left(\mathrm{g} \mathrm{day}^{-1}\right)$, nitrogen feces $\left(\mathrm{g} \mathrm{day}^{-1}\right)$, nitrogen digestibiliy $(\%)$, nitrogen in urine $\left(\mathrm{g} \mathrm{day}^{-1}\right)$, and nitrogen balance $\left(\mathrm{g} \mathrm{day}^{-1}\right)$. The independent variables were diet, season, and trial. Least squares means were used to test the differences among diets and seasons. A diet $X$ season interaction was observed and a second analysis was conducted in which season was pooled for the alfalfa and Coastal bermuda grass hay (the same materials were fed during both seasons) but considered separately for live oak forage (LO) and ash foliage/Bermuda grass (Jun/CBH) treatments.

\section{Results and Discussion}

Forage intake did not differ $(\mathrm{P}=$ $0.79)$ between spring and fall trials (944 vs $962 \mathrm{~g} \mathrm{day}^{-1}$ respectively). However, during spring, goats digested

\begin{tabular}{|c|c|c|c|c|c|c|c|}
\hline \multirow[b]{2}{*}{ Parameter } & \multirow{2}{*}{$\begin{array}{l}\text { Coastal } \\
\text { bermuda- } \\
\text { grass hay }{ }^{2}\end{array}$} & \multirow{2}{*}{$\begin{array}{l}\text { Alfalfa } \\
\text { hay }\end{array}$} & \multicolumn{2}{|c|}{ Live oak } & \multicolumn{2}{|c|}{ Ashe juniper $^{1}$} & \multirow[b]{2}{*}{ SE } \\
\hline & & & Spring & Fall & Spring & Fall & \\
\hline Number of goats & 10 & 10 & 4 & 6 & 4 & 6 & \\
\hline Dry matter intake (g/day) & $1430^{\mathrm{a}}$ & $1228^{\mathrm{a}}$ & $1187^{\mathrm{ab}}$ & $914^{\mathrm{b}}$ & $545^{\mathrm{c}}$ & $564^{\mathrm{c}}$ & 96.1 \\
\hline Feces (g/day) & $511^{\mathrm{a}}$ & $459^{\mathrm{a}}$ & $458^{\mathrm{a}}$ & $451^{\mathrm{a}}$ & $193^{\mathrm{b}}$ & $300^{\mathrm{b}}$ & 36.4 \\
\hline Dry matter dig, (\%) & $64.3^{\mathrm{a}}$ & $62.6^{\mathrm{a}}$ & $61.4^{\mathrm{a}}$ & $50.7^{\mathrm{b}}$ & $64.6^{\mathrm{a}}$ & $46.8^{\mathrm{b}}$ & 4.6 \\
\hline Water intake (litter/day & $7.2^{\mathrm{a}}$ & $6.7^{\mathrm{a}}$ & $5.5^{\mathrm{ab}}$ & $1.8^{\mathrm{c}}$ & $6.7^{\mathrm{a}}$ & $2.7^{\mathrm{bc}}$ & 1.1 \\
\hline Urine excreted (litter/day) & $4.3^{\mathrm{a}}$ & $4.3^{\mathrm{a}}$ & $2.9^{\mathrm{ab}}$ & $.9^{\mathrm{b}}$ & $4.0^{\mathrm{a}}$ & $2.4^{\mathrm{ab}}$ & .75 \\
\hline Nitrogen intake (g/day) & $39.8^{\mathrm{a}}$ & $37.7^{\mathrm{a}}$ & $12.0^{\mathrm{bc}}$ & $14.4^{\mathrm{b}}$ & $4.1^{\mathrm{d}}$ & $5.8^{\mathrm{cd}}$ & 2.36 \\
\hline Nitrogen in feces (g/day) & $10.7^{\mathrm{a}}$ & $8.2^{\mathrm{b}}$ & $7.4^{\mathrm{b}}$ & $6.6^{\mathrm{bc}}$ & $1.9^{\mathrm{d}}$ & $4.2^{\mathrm{a}}$ & .77 \\
\hline Nitrogen digestibility (\%) & $73.1^{\mathrm{a}}$ & $78.2^{\mathrm{a}}$ & $38.3^{\mathrm{a}}$ & $54.2^{\mathrm{b}}$ & $53.7^{\mathrm{b}}$ & $27.6^{\mathrm{c}}$ & 5.78 \\
\hline Nitrogen in urine (g/day) & $20.1^{\mathrm{a}}$ & $14.5^{\mathrm{b}}$ & $5.2^{\mathrm{a}}$ & $4.5^{\mathrm{c}}$ & $8.0^{\mathrm{c}}$ & $5.8^{\mathrm{c}}$ & 1.48 \\
\hline Nitrogen balance (g/day) & $8.9^{\mathrm{b}}$ & $15.0^{\mathrm{a}}$ & $-.6^{\mathrm{d}}$ & $3.4^{\mathrm{cd}}$ & $5.8^{\mathrm{bc}}$ & $3.7^{\mathrm{c}}$ & 1.28 \\
\hline
\end{tabular}
more dry matter $(P=0.06)$, consumed more water $(\mathrm{P}<0.001)$, and produced more urine $(\mathrm{P}<0.001)$ than during fall (Table 1). Dry matter concentrations were similar in the spring and fall seasons for live oak and juniper.

Nitrogen content was highest in the alfalfa hay, slightly lower in the Coastal bermudagrass hay and lowest for live oak and juiper foliage (Table 2 ). These values indicate a typical high-quality alfalfa, a highly fertilized
Coastal bermudagrass hay that may have contained up to $1 \%$ or more nonprotein nitrogen, and live oak and ashe juniper foliages that were within the ranges of those reported previously from the research site (Huston et al. 1981). The higher fall values were surprising, especially for live oak, which usually contains higher nitrogen during spring $(>1.6 \%)$ then declines as current season leaves age. However, the nitrogen contents of these foliages are influenced by moisture and temperature conditions, which may have modified the usual pattern. This finding is consistent with the similarity in forage moisture contents (spring vs fall) and large differences in water consumption. Generally, spring foliage is lower in dry matter content. Water intake and urine volume of goats was greater on the hay than the shrub diets which may be a reflection of the higher protein content and dry matter intake of the hays.

Intakes of the hays were higher than those of the shrub foliage, although intake of juniper $\left(555 \mathrm{~g}\right.$ day $\left.^{-1}\right)$ was only part of total intake (total Jun/CBH intake $\left.=975 \mathrm{~g} \mathrm{day}^{-1}\right)$. Intake of live oak was greater than intake of ashe juniper. Live oak is more palatable than ashe juniper (Taylor unpublished data), possibly because tannins in live oak are less aversive than terpenoids in ashe juniper. This concept is supported by higher intake of live oak during spring when tannins would be higher in concentration. 


\begin{tabular}{|c|c|c|c|c|c|c|}
\hline \multirow[b]{2}{*}{ Parameter } & \multirow{2}{*}{$\begin{array}{l}\text { Coastal } \\
\text { bermuda- } \\
\text { grass hay }^{2}\end{array}$} & \multirow{2}{*}{$\begin{array}{l}\text { Alfalfa } \\
\text { hay }\end{array}$} & \multicolumn{2}{|c|}{ Live oak } & \multicolumn{2}{|c|}{ Ashe juniper $^{1}$} \\
\hline & & & Spring & Fall & Spring & Fall \\
\hline Dry matter (DM) (\%) & 90.0 & 90.0 & 61.4 & 62.4 & 64.7 & 57.5 \\
\hline Nitrogen \% of DM & 2.78 & 3.07 & 1.01 & 1.58 & 0.75 & 1.02 \\
\hline
\end{tabular}

The spring foliages of both shrubs were similar in digestibility to the hays but lower during the fall. Therefore, spring foliages from both shrubs were similar to the hays in their capacities to provide digestible energy if similar levels of intake could be obtained. In these trials and as previously noted, intake of live oak was relatively high yet still lower than the hays, and animals will not readily consume juniper as a single diet ingredient. It is suggested that for digestible energy purposes, both foliages should be considered as high value during spring and when consumed as a component of multi-component diets. Similarly, the fall values, though lower than during spring, compare favorably with most alternative dietary components on fall rangeland in the region (Huston et al. 1981).

Larger differences were observed between diets and seasons for nitrogen digestion/metabolism. Although nitrogen intake was similar for the 2 hays (slightly higher for Coastal bermudagrass hay), nitrogen in Coastal bermudagrass hay was nonprotein, rapidly absorbed and excreted in the urine. The low digestibility of nitrogen and negative nitrogen balance for spring live oak reflected the high tannins in that foliage (Nastis and Malechek 1981) compared with the fall foliage. For ashe juniper, the fall foliage nitrogen was less digestible and contributed to a lower nitrogen balance. Immature ashe juniper has lower concentrations of terpenoids than mature juniper (Taylor et al 1997). Although juniper is an evergreen, goats tend to select the more immature growth thereby minimizing the interference factor that may be associated with terpenoids. The actual nitrogen balance values reported are for the combined diet (Jun/CBH) because the urinary excretion of nitro- gen was not partitioned according to source. Overall, these data confirm that these shrub foliages are of less value as a nitrogen source than for an energy source compared with the hays included in the study.

\section{Summary and Management Implications}

Voluntary intake, rather than digestibility, seems to limit the nutritional value of live oak and Ashe juniper foliage for goats. Phytochemicals in live oak (tannins) and especially in juniper (terpenoids) are negatively related to intake. Although many phytochemicals in forages and browse plants reduce intake (Bryant 1992; Bush and Burton 1994), the overall effects on animal metabolism are varied and sometimes beneficial. Tannins are known to bind protein which can prevent its degradation in the reticulorumen and increase the proportion of dietary amino acids that are subjected to intestinal digestion. This can be important when specific amino acids limit protein synthesis. Feeding of live oak leaves increased nitrogen retention and mohair growth in Angora goats (Huston and Shelton 1967). However, Pritz et al. (1997) reported that nitrogen balance of goats may be negatively affected when substantial amounts of juniper are consumed.

The energy requirements of a $40 \mathrm{~kg}$ Angora female at maintenance (low activity), while pregnant, and during lactation $(1 \mathrm{~kg}$ of $4 \%$ fat-corrected milk per day) are approximately 2.7, 3.7, and 4.2 Mcal digestible energy (DE) per day, respectively (NRC 1981). Estimating that each Mcal DE would be equivalent to $225 \mathrm{~g}$ of digestible dry matter, requirements would be approximately 608,832 , and
$945 \mathrm{~g} \mathrm{day}^{-1}$ for an Angora female at maintenance, while pregnant, and during lactation, respectively. Other species (e.g. sheep) consume similar amounts of forage when at maintenance and while pregnant but approximately 35\% more during lactation (Huston and Engdahl 1983). The Angora muttons used in the digestion trial weighed approximately $40 \mathrm{~kg}$ and consumed 582, 309, 919, and $769 \mathrm{~g}$ digestible dry matter from live oak, juniper/Coastal bermudagrass hay, Coastal bermudagrass hay, and alfalfa hay, respectively. Because animals tend to eat less in stalls than while grazing, both Coastal bermudagrass hay and alfalfa hay seem adequate for Angora goats whether at maintenance, while pregnant, or during lactation. However, live oak and juniper (even in a mixture with Coastal bermadagrass hay) though probably adequate for maintenance, were inadequate for goats that are either pregnant or lactating. Ashe juniper, as well as live oak can provide nutrients at important periods in a goat's annual production cycle but probably only as partial diets. The intake of a pure diet of juniper forage would be too low for maintenance. Volatile oil concentrations in juniper may limit the amount of dry matter that can be consumed and metabolized. However, ashe juniper is of sufficiently high quality (i.e., $50 \%$ DMD) to significantly contribute to the diets of grazing/browsing animals that have access to other forages and/or supplemental feeds.

\section{Literature Cited}

A.O.A.C. 1965. Official Methods of Analysis (10th Ed.) Assoc. of Official Agr. Chem. Washington, D.C.

Bryant, J.P., P.B. Reichardt, and T.P. Clausen. 1992. Chemically mediated interactions between woody plants and browsing mammals. J. Range Manage. 45:18-24.

Bush, L. and H. Burton. 1994. Intrinsic chemical factors in forage quality. In: G.C. Fahey, Jr. (Ed.) Forage Quality, Evaluation, and Utilization. pp 367-405. Amer. Soc. Agron., Inc.; Crop Sci. Soc. Amer., Inc.; Soil Sci. Soc. Amer., Inc. Madison, Wisc. 
Fuhlendorf, S.D. and F.E. Smeins. 1997. Long-term vegetation dynamics mediated by herbivores, weather and fire in a Juniperus-Quercus savanna. J. of Veg. Sci. 8:819-828.

Fuhlendorf, S.D., F.E. Smeins, and C.A. Taylor, Jr. 1996. Browsing and tree size influences on Ashe Juniper Understory. J. Range Manage. 50:507-512.

Hatch, S.L., K.N. Gandhi, and L.E. Brown. 1990. Checklist of the vascular plants of Texas. Texas Agr. Exp. Sta. Rep. MP-1655. 158 pp.

Huston, J.E. and B.S. Engdahl. 1983. Intake in ewes at four levels of supplemental feed during fall, winter, and spring. Texas Agr. Exp. Sta. Prog. Rep. CRP-4171. pp. 48-52.

Huston, J.E. and M. Shelton. 1967. Effect of live oak leaves on protein utilization and mohair production of Angora goats. Texas Agr. Exp. Sta. Prog. Rep. PR-2451.

Huston, J.E., B.S. Rector, L.B. Merrill, and B.S. Engdahl. 1981. Nutritional value of range plants in the Edwards Plateau region of Texas. Texas Agr. Exp. Sta. Bull. B-1357.

Nastis, A.S. and J.C. Malechek. 1981. Digestion and utilization of nutrients in oak browse by goats. J. Anim. Sci. 53:283-290.
NRC. 1981. Nutrient requirements of goats; Angora, dairy, and meat goats in temperate and tropical countries. Nat. Acad. Press, Washington, D.C.

Pritz, R.K., K.L. Launchbaugh, and C.A. Taylor, Jr. 1997. Effects of breed and dietary experience on juniper consumption by goats. J. Range Manage. 50:600-606.

Riddle, R.R., C.A. Taylor, Jr., M.M. Kothmann, and J.E. Huston. 1996. Volatile oil contents of ashe and redberry juniper and its relationship to preference by Angora and Spanish goats. J. Range Manage. 49:35-41.

Rykiel, E.J. and T.L. Cook. 1986. Hardwood redcedar clusters in the post oak savanna of Texas. Southw. Natur. 31:73-78.

SAS. 1988. SAS/STAT User's Guide (Release 6.03). SAS Inst. Inc., Cary, N.C.

Smeins, F.E. 1990. Ashe juniper: Consumer of Edwards Plateau rangeland. TAES Tech. Rep. No. 90-1.

Smeins, F.E. and L.B. Merrill. 1988. Long-term change in a semi-arid grassland, p. 101-114. In: B.B. Amos and F.R. Gehibach (eds), Edwards Plateau vegetation: Plant ecological studies in central Texas. Baylor Univ. Press, Waco, Tex.
Smeins, F.E., T.W. Taylor, and L.B. Merrill. 1976. Vegetation of a 25-year exclosure on the Edwards Plateau, Texas. J. Range Manage. 29:24-29.

Taylor, C.A., Jr. 1992. Brush management considerations with goats. pp. 144-145. In: J.C. Paschel and W. Hanselka (ed.), Proc. of International conference on meat goat production. Tex. Agr. Ext. Serv., College Station, Tex.

Taylor, C.A. Jr., T.D. Brooks, and N.E. Garza. 1993. Effects of short duration and high-intensity, low-frequency grazing systems on forage production and composition. J. Range Manage. 46:118-122.

Taylor, C.A., Jr., K.L. Launchbaugh, J.E. Huston, and E. Straka. 1997. Improving the efficacy of goating for biological juniper management. p. (5-17)-(5-22). In: C.A. Taylor, Jr. (ed), 1997 Juniper Symposium, Texas A\&M Res. and Ext. Center, San Angelo, Tex.

USDA-SCS. 1972. Technical guides section IIe, range site description, low stony hills range site, PE-19-25. Major land resource area for the Edwards Plateau, Texas Soil Consv. Serv., Temple, Tex.

Youngblood, B. and A.B. Cox. 1992. An economic study of a typical ranching area on the Edwards Plateau in Texas. Texas Agr. Exp. Sta. Bull. 297. 